\title{
低侵壟医療技術と精遙工学
}

\section{マイクロ・ナノマシニング技術を用いた 低侵襲医療機器の開発*}

Development of Minimally Invasive Medical Devices Using Micro/nano Machining Technology

\section{芳賀洋一** 松永忠雄 ${ }^{* *}$ 江刺正喜*** \\ Yoichi HAGA, Tadao MATSUNAGA and Masayoshi ESASHI}

Key words minimally invasive treatment, micromachining, MEMS, catheter, endoscope

\section{1.はじめに}

内視鏡やカテーテルを用いた低侵襲医療技術の発展に伴 い, 細く小さくとも高機能・多機能な医療ツールのニーズ が高まっている. 精密な微細加工技術, 特にマイクロマシ ニング技術や MEMS（微小電気機械システム）技術など を用いることで, 今までにない高機能・多機能な医療ツー ルが実現できる。これらの次世代医療ツールは安全かつ確 実な計測や診断の他, 今まで不可能だった新しい治療や, 人体の機能解明にも役立つと期待される.

\section{2. 低侵襲医療と微細加工技術}

低侵襲医療は，体を大きく切開せずに，内視鏡やカテー テルと呼ばれる医療用チューブなどを体内に挿入して従来 の手術に匹敵する検查や治療を行うもので, 患者の身体 的, 精神的負担を減らせる他, 入院期間を短縮し医療費の 削減にも役立つ。内視鏡には主に胃や腸など消化管に用い られる屈曲可能な軟性鏡と, 胆囊摘出術など腹腔鏡手術に 多く用いられる棒状の硬性鏡がある. カテーテルは外径数 百 $\mu \mathrm{m}$ 数 $\mathrm{mm}$ 程度の医療用ポリマーチューブで, 血管内

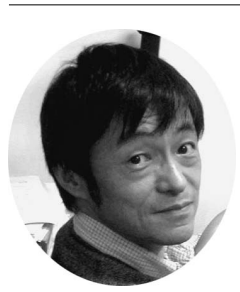

*原稿受付 平成 20 年 9 月 30 日

**東北大学大学院医工学研究科（宮城県仙台市青 葉区荒卷字青葉 6-6-04)

**正 会 員 東北大学原子分子材料科学高等研究 機構（宮城県仙台市青葉区荒巻字青葉 6-6-01） 芳賀洋一

1992 年東北大学医学部卒. 1994 1996 年東北 厚生年金病院勤務. 1996 年東北大学大学院工学 研究科助手, 2008 年同医工学研究科教授となり 現在に至る. マイクロマシン・MEMS 技術を用いた医療機器の研究に従 事. 医学博士㧍よび工学博士.

松永忠雄

1994 年佐賀大学理工学部電気工学科卒. 同年 4 月, 曙ブレーキ工業株式会 社入社. 2008 年 4 月, 東北大学大学院医工学研究科, 助教, 現在に至る. MEMS を用いた低侵襲医療デバイス, 福祉機器の研究開発に従事. 工学博 士.

\section{江刺正喜}

1971 年東北大学工学部電子工学科卒. 1976 年同大学院博子課程修了. 工学 博士. 同助手, 助教授を経て現在原子分子材料科学高等研究機構教授. 又 イクロセンサや MEMS の研究に従事.「半導体集積回路設計の基礎」(1981 年) 培風館他著書多数.
などに挿入して用いられる.内視鏡を用いた治療として体 内局所のがん, ポリープの摘出や胆囊摘出術が, カテーテ ルを用いた血管内治療として血管狭窄部を内側から広げる ことや脳動脈瘤に詰め物をして破裂を防ぐことなどが行わ れる.内視鏡やカテーテルを用いた低侵襲医療は様々な利 点の一方で, 視野が狭い, 操作性が劣る, 術者の習熟に時 間がかかるなどの久点もある。 さらに低侵襲医療の新しい 手法や治療対象の広がりに伴い, 術者の習熟が追いつかな いなどの問題も出てきている.

このような問題を工学技術によって解決する試みがいく つかなされている。例えば硬性鏡の操作をロボット化した ロボット外科手術や, 飲み込むことで体内の映像をワイヤ レスで体外に送信するカプセル内視鏡がある。しかし，口 ボット外科手術は体内に挿入するッール内のワイヤーを体 外の電動モー夕で劧引し, 鉗子やナイフなどを動かすシス テムであり, シャフトの柔軟性, 多機能化, 細径化が求め られている軟性鏡にそのまま適用することは難しい。ま た，システムが大がかりになる欠点もある．カプセル内視 鏡は小腸など従来の内視鏡が到達しにくい場所を患者の負 担なく観察できる点で有用であるが, 体内に扔けるカプセ ルの移動や位置合わせの制御は難しく、内視鏡で行われて いる生検や治療には適さない. また, 消化管以外, 例えば 血管内でカプセル状のワイヤレスシステムを用いるには, 安全に回収, または体内で代謝・分解される必要や, 移動 の制御，小型化に伴うエネルギー供給の問題などを解決し なければならない.

低侵襲医療の新しい流れとして鼻腔から挿入する経鼻内 視鏡, 軟性内視鏡を用い胃や子宮を経由して腹腔内治療ま でも行う NOTES (Natural Orifice Transluminal Endoscopic Surgery), 高周波アブレーションカテーテル による心腔内からの不整脈治療, 子宮内に打ける胎児手 術，などがある。これらに用いられる内視鏡やカテーテル は, より細く小さく, より精度良く, 安全かつ確実に検査 および治療が行えることが求められている。このような要 求を満たすには, マイクロマシニング, MEMS などの微 細加工技術と新しい材料技術が役立つ. 


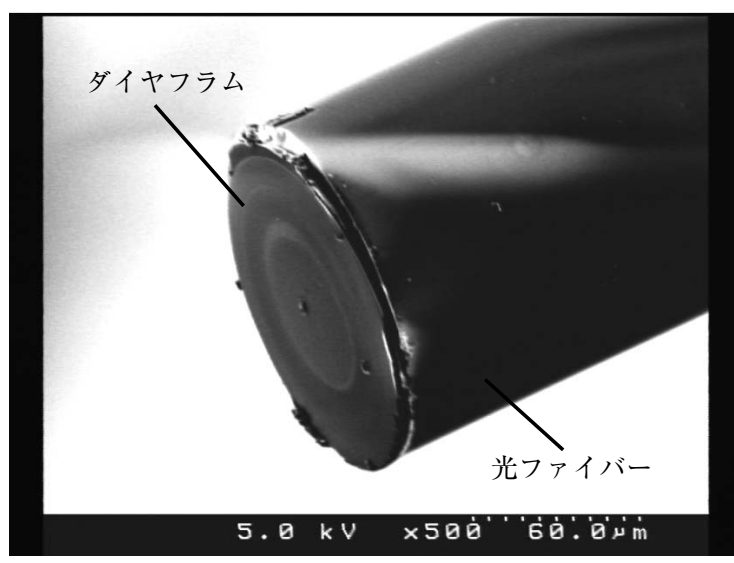

図 1 極細径光ファイバー圧力センサ（外径 $125 \mu \mathrm{m}$ )

マイクロマシニング技術が切削やレーザー加工などの精 密加工技術を含むのに対し，MEMS 技術は，集積回路な どを作製する半導体プロセス技術を発展させマイクロセン サやマイクロアクチュエータなど微小な機械要素までも一 括で作製する技術を含む。これらの技術を駆使した微小 化・高機能化により患者の負担を減らせるばかりでなく， いままで到達が不可能だった部位での検査・治療が可能に なり，多機能化により複数項目の同時検査・観察，および 治療ができ，今までにない精密で複雑な手技が可能とな る．特に，マイクロセンサやマイクロアクチュエータを利 用することで内視鏡やカテーテルの先で，より高精度な組 織レベル，細胞レベル，さらには分子レベルの検査・治療 が体内局所で実現できるようになると期待される.

高価なため, やむを得ず滅菌して再使用される軟性内視 鏡を除き，体内で用いられる医療機器は，血液や体液を介 した感染を防ぐために基本的に使い捨て（ディスポーザブ ル）であり，量産性に優れた微細加工技術，MEMS 技術 などによる一括作製の技術が求められる。

ここでは，われわれの開発例を示しながら，マイクロマ シニング技術，MEMS 技術を用いた低侵襲医療機器開発 の現状と今後の展望について述べさせていただく．

\section{3. 極細径光ファイバー圧カセンサ}

光ファイバーを用いた直径 $125 \mu \mathrm{m}$ 程度の極細径血圧セ ンサを図 1 に示す ${ }^{1)}$. MEMS プロセスにより作製された $0.7 \mu \mathrm{m}$ 厚のシリコン酸化膜ダイヤフラムが直径 $125 \mu \mathrm{m}$ の 光ファイバー端面に形成されており，圧力によるダイヤフ ラムのたわみを白色光の干渉スペクトル変化を用い計測す ることで体内局所の血圧を計測する。従来の血圧センサで は挿入不可能な狭い空間に挿入できるので，血管内狭窄部 をバルーンカテーテルで広げたり，逆に血管を塞栓すると いった治療前後の血行動態を把握する際，さらに1本のカ テーテルやガイドワイヤーに複数のセンサを搭載し，場所 による圧力の違いを多点同時計測することなどが可能にな る。 センサ構造体は MEMS プロセスを用いてシリコンウ エハー上に多数のダイヤフラム構造を一括で作製し，その

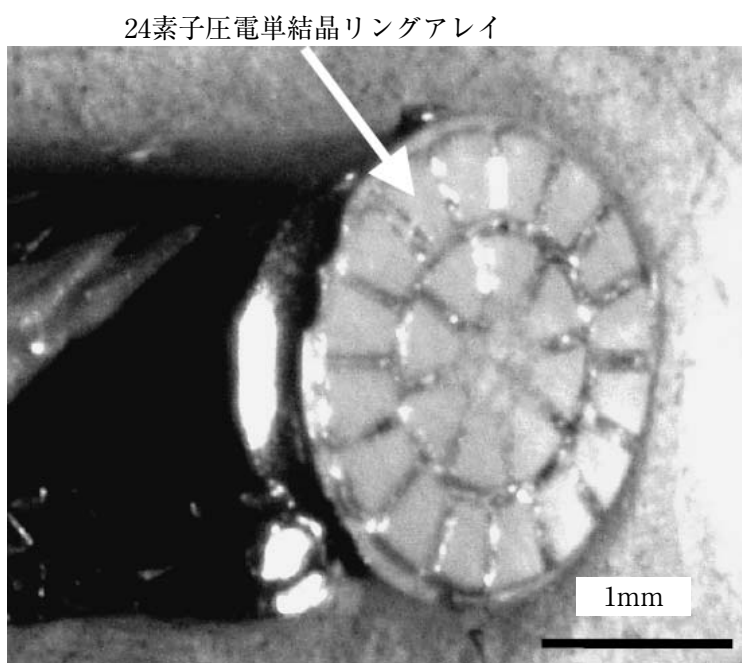

図 2 血管内前方視超音波内視鏡（外径 $2.5 \mathrm{~mm}$ )

後, 反応性イオンエッチング（RIE）で貫通エッチングを 行いダイヤフラムをもった多数の円柱形状パーツを一括作 製する。 ガラス毛細管内で光ファイバー端面にポリイミド 層を介して円柱パーツを熱圧着した後，二フッ化キセノン $\left(\mathrm{XeF}_{2}\right)$ によるエッチングでシリコン円柱部を選択的に除 去する。 センサ部が小さいので 1 回のプロセスで 1 枚のシ リコンウェハーから数十万個という膨大な数のダイヤフラ ム構造体を得ることができる。

\section{4. 血管内前方視超音波内視鏡}

血管内治療を安全かつ確実に行うため, カテーテル先端 に搭載する前方視超音波内視鏡を開発している．血管内狭 窄部に直接触れることなくカテーテル進行方向の血管走行 や病変部の形状を 3 次元的に超音波イメージングすること が原理的に可能であり，これにより安全な血管内手術が実 現できると期待される。ガイドワイヤーを体外から操作し て血管内狭窄部を通り抜ける際や，完全に閉塞した血管内 病変部に硬いガイドワイヤーを押し進め再開通させる手術 の際に，血管壁や血管内病変を傷つけることなく安全に治 療が行えるようになると期待される。画像構成はカテーテ ル端面に実装された複数の超音波トランスデューサ素子を 1つずつ切り替えて超音波パルスを発信し組織からの反射 エコーをすべての素子で受信しコンピュータ上で遅延処 理, 画像構成処理することで行う. 外径 $3 \mathrm{~mm}$ のプローブ を用い，基本的な撮像実験に成功している2). さらに，素 子を増やすことでアーチファクト（虚像）の低減を図り， $20 \mathrm{MHz}$ に高周波化することによって解像度の向上を目指 している（図2）。この際, 微小な素子でも高い超音波強 度，高感度を実現するため PZTよりも圧電特性に優れる 圧電単結晶の PMN-PT を用いている。その他，内視鏡や カテーテル先端から集束した超音波を組織に照射し精密な 超音波治療，例えば超音波と薬剤の相乗効果によって，が んなどを治療する音響力学療法 (Sonodynamic Therapy： SDT）や, 超音波による遺伝子導入（Sonoporation）を行 
うための小型集束超音波プローブも開発し，in vitroでの 細胞への遺伝子導入に成功している ${ }^{3)}$.

\section{5. 形状記憶合金を用いた能動屈曲カテーテル}

\section{1 能動カテーテル}

先端にマイクロアクチュエータを搭載し, その動作を体 外から自在にコントロールする能動カテーテルや能動ガイ ドワイヤーを開発している ${ }^{4)}$. Ni-Ti 合金製の形状記憶合 金（SMA; Shape Memory Alloy）マイクロコイルをアク チュエータとして用いており，これをカテーテル先端付近 に実装することで屈曲，ねじれ回転や伸縮など様々な動き を実現できる.SMA コイルは素線径が数 $10 \mu \mathrm{m}$ 程度と細 い場合，電気抵抗が比較的高く，外部からコイル素線へ電 流を流す直接通電加熱により各部を自由に動かすことがで きる，体内で用いる場合，加熱時の SMA 温度に気をつけ る必要があるが，発熱体である SMA コイルを外装からや や内側に配置して表面とSMA の間にすき間をもたせ熱を 伝わりにくくすることで，体内でも使用が許される表面温 度で動作できる。なお，マイクロアクチュエータには SMA の他, 静電アクチュエー夕，圧電アクチュエータな ど様々なものがあるが，低侵襲医療ツールに求められるサ イズと形状, 大きな発生力と変位を満たすものは少なく, この分野における発展を妨げている。

屈曲機構の具体的な応用例をひとつ示す．腸閉塞（イレ ウス）治療のひとつとして，長さ 2 メール程度のシリコ ーンゴム製チューブを通過障害を起こした体内深部の腸ま で挿入し，腸液やガスを体外から持続吸引する腸管内減圧 法が行われる。しかし，このチューブを胃の出口である狭 い幽門部に通過させることが難しく，術者や患者にとって 負担が大きい。 そこで，1 方向 1 関節の SMA を用いた能 動屈曲機構をチューブの先端に搭載し，短時間で確実に挿 入できる腸閉塞治療用能動屈曲チューブを開発した。腸閉 塞治療用チューブはシャフトが長く柔らかいので，内視鏡 のようにワイヤーをシャフトに内蔵して体外から衰引する と座屈が生じ, 先端の精密な屈曲動作は難しい。屈曲部の 外径は約 $6 \mathrm{~mm}$, 屈曲部長さ $40 \mathrm{~mm}$, 最大屈曲角度は $110^{\circ}$ である

\section{2 能動屈曲電子内視鏡}

胃や大腸に挿入される軟性内視鏡は，体外からワイヤー を用いて牽引し先端を屈曲させる構成のため，シャフトを より細く長く，かつ柔らかくするには限界がある。 カプセ ル内視鏡は小腸など体内奥深くへ容易に到達できるが，内 視鏡が鉗子口を通してツールを挿入して行なう生検や治療 手技には適していない.SMA を用いて多方向に曲がるこ とができる屈曲機構先端に CCD や CMOS イメージャー を搭載した能動屈曲電子内視鏡を開発している ${ }^{6)}$. 体内の 奥深くに容易に到達し，必要に応じチューブ内腔を通して 生検や治療が行える他，屈曲機構を低コスト化できるので 使い捨て化も可能と期待される. 図 3 に試作したデバイ スを示す．ジョイスティックを用い好きな方向と角度に先

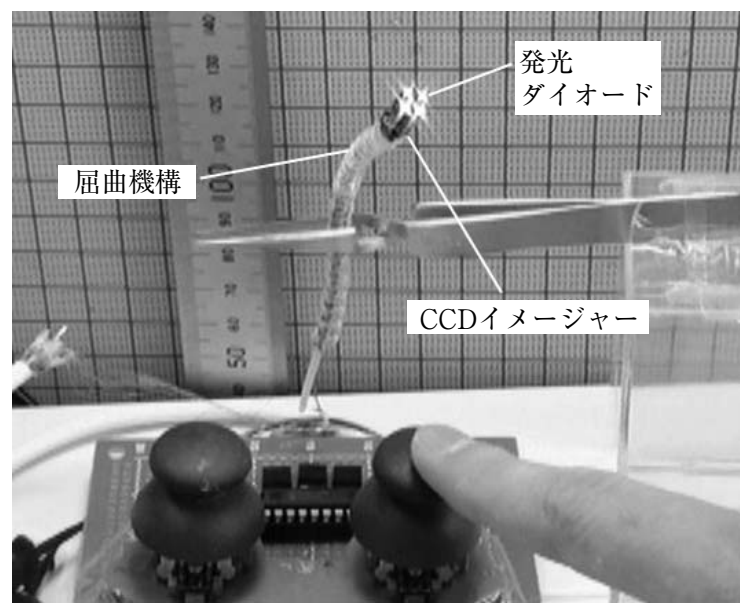

図 3 能動屈曲電子内視鏡（外径 $5.5 \mathrm{~mm}$ )

端を動かすことができ，先端に搭載された発光ダイオード （LED）で内部を照らし，イメージャーを用い見回し観察 ができる．外径 $10 \mathrm{~mm}$ 程度の使い捨てを目指した大腸用 能動屈曲電子内視鏡も開発している.

\section{6. 非平面フォトファブリケーションの開発とその応用}

一般に低侵襲医療ツールはチューブ形状であることが望 ましく, 内視鏡やカテーテルでは，チューブ内腔は薬液・ 造影剤の注入や，ガイドワイヤー・鉗子などマイクロツー ルの挿入に利用される。しかし MEMS 技術は一般に平ら なシリコンウェハー上での作製を中心に発展してきたた め, チューブのような三次元形状へそのまま適応するには 困難な場合が多い.チューブ表面のような曲面や三次元形 状に適したフォトファブリケーション技術のひとつとし て，直径 2 $3 \mathrm{~mm}$ 程度の円筒面上にレーザー照射を利用 したマスクレスフォトリソグラフィを行い金属ソレノイド コイルパターンや，絶縁層を介した多層金属パターンを作 製した．露光光を微小点で照射しサンプルの位置を多軸ス テージで制御することにより描画するほか，複雑なパ夕ー ンに対応するため DMD（デジタルマイクロミラーデバイ ス）を用いた露光装置を改造して用いている。チューブ形 状の高機能パーツは，主に手作業で行われている内視鏡や カテーテルの組立と相性が良く，実用化に有利と考えてい る.

\section{1 光ファイバー電磁駆動細径内視鏡}

開発した上述の非平面プロセスを用いて光ファイバー 1 本を電磁的に振動させ, 細径でも高画質の光学的観察を行 える内視鏡を開発している。コリメートレンズ付き光ファ イバー 1 本を電磁的に 2 次元走査させることで, 充分に速 い取り込み速度により時間的に多数のファイバーを仮想的 に並べることになり，高解像度の 2 次元画像を得ることが できるファイバースコープになる。試作したデバイスを図 4 に示す.コイルは円筒面上へフォトレジストのパターニ ングと，レジストを型にした銅の電解めっきを用いてポリ イミドチューブ上へ作製される. 長軸方向に磁化された永 


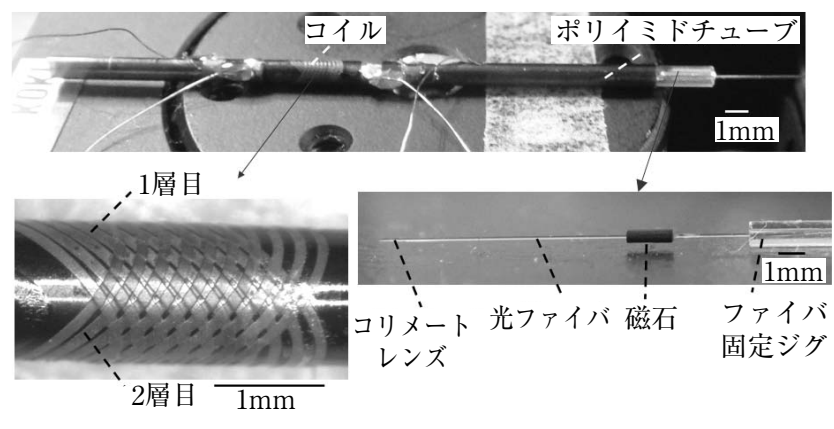

图 4 光ファイバー電磁駆動細径内視鏡（外径 $1 \mathrm{~mm}$ )

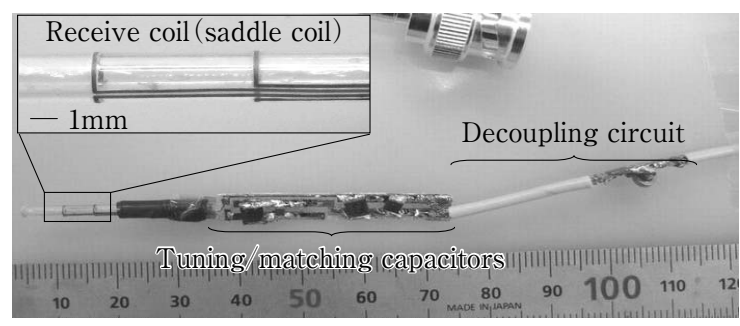

Porcine subclavian artery

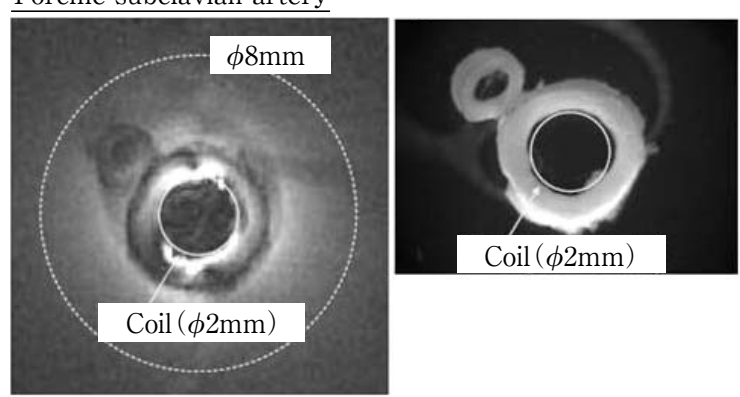

図 5 血管内 MRI プローブ（外径 $2 \mathrm{~mm}$ ） と撮像結果（ブタ鎖骨下 動脈)

久磁石が光ファイバーに取り付けてあり, 傾斜コイルに電 流を流すと光ファイバーが斜めに傾く，直交した 2 層の傾 斜コイルを用いて光ファイバーを 2 次元走査することがで き, 正面視 (直視) 観察が可能となる。 また, 深さ分解能 $10 \mu \mathrm{m}$ 程度の観察ができる OCT（光干渉断層撮像法）と 組み合わせると，1 次元走查すれば組織の断面が7)，2 次 元走査すれば 3 次元の組織像を得ることができる。このよ うな細径で解像度の良い内視鏡は，血管内や乳管内，さら に歯根部の根尖病巣などの観察治療などに役立つ。その 他，体内で精密なレーザーアブレーション治療を行うため の側視型プローブも開発している。

\section{2 血管内 MRI プローブ}

開発した非平面プロセスを用いて, 直径 $2 \mathrm{~mm}$ 程度の MRI（磁気共鳴イメージング）受信コイルをカテーテル先 端付近に搭載した血管内 MRI プローブを開発している ${ }^{8)}$. 従来の MRI では，体外の励起コイルにより組織から発生 する核磁気共鳴（NMR）信号を体外の受信コイルによっ て受信し像が構成される，血管内に小型受信コイルを挿入 し，撮像対象の近くで受信することで信号強度と $\mathrm{S} / \mathrm{N}$ 比 が向上し高解像度のイメージングができる。これにより動
脈硬化や㤡状硬化，動脈瘤などの病変をより精密に観察， 診断できる，試作したコイルを用いて摘出ブ夕血管の撮像 を確認している（図 5)。今後, コイルデザインの最適化 コイルの多層化による高性能化, 抢よびカテーテルの形状 と機能を損なわず高周波信号を効率よく取り出すためのコ ンデンサなどを先端付近に搭載することを検討している.

\section{7.おわりに}

微細加工技術を用いた新たな低侵襲医療機器開発につい て述べた，低侵襲医療分野の実用化は，比較的安定したマ 一ケットと，使い捨てに伴う消費量の多さなど利点がある 一方で，市販するまでには許認可が必要なため多大な時間 と費用を要する．MEMSのように高額でランニングコス トのかかる製造設備を導入し長期的に開発を行うことは一 般の医療機器メーカーには難しく, 実用化のためには製造 プロセスの一部を請け負うファウンダリーの活用や，その 他様々な工夫や新たな仕組み作りが必要である。その一方 で，微細加工技術が提供できる高い信頼性，高機能は医療 用途に不可欠であり, 様々な障害はあるものの, 微細加工 技術分野に抒ける今後の技術的進歩と, 患者㧍よび医療従 事者の要望に支えられ, 今後一層, 新たな医療機器開発が 行われていくであろう。午の先には，かつての SF 映画, ミクロの決死圈のように，まるで医師と治療機械が小さく なって体内で作業をするようなリアルなインターフェース を術者に提供できる可能性や，体内から病変部を細胞レベ ル，さらには分子レベルで精密に検査治療できる可能性， また，今後数十年の間に，現時点では思いもつかなかった 新たな検査・治療を可能にする低侵襲医療ツールが実現さ れる可能性があり，心をワクワクさせる夢は尽きない．

\section{参 考 文 献}

1) T. Katsumata, Y. Haga, K. Minami and M. Esashi: Micromachined $125 \mu \mathrm{m}$ Diameter Ultra Miniature Fiber-Optic Pressure Sensor for Catheter, Trans. IEE of Japan, 120-E, 2 (2000) 58 .

2）陳俊傑, 江刺正喜, 大城理, 千原國宏, 芳賀洋一：血管内低侵 襲治療のための前方視超音波イメージャーの開発，生体医工学， 43, 4 (2005) 553.

3）安居晃啓, 芳賀洋一, 陳俊傑, 伊関洋, 江刺正喜, 和田仁: 小 型収束超音波卜ランスデューサを用いた内視鏡的治療デバイス， 電気学会論文誌 E, 127, 2 (2007) 69

4）芳賀洋一, 江刺正喜: 屈曲, ねじれ, 伸長能動カテーテルの電 気めっきによる組み立て, 電気学会論文誌 $\mathrm{E}, \mathbf{1 2 0}, 11$ (2000) 515 .

5）水島昌徳，芳賀洋一，戸津健太郎，江刺正喜：形状記憶合金を 用いた腸閉塞治療用能動カテーテル，日本コンピュータ外科学 会誌, 6, 1 (2004) 23.

6）牧志渉, 松永忠雄, 江刺正喜, 芳賀洋一：形状記憶合金を用い た能動屈曲電子内視鏡, 電気学会論文誌 E, 127, 2 (2007) 75 .

7) T. Matsunaga, R. Hino, W. Makishi, M. Esashi and Y. Haga: Endoscopic Optical Coherence Tomography Probe Using Electromagnetically Vibration of Single Fiber, Technical Digest of the 25th Sensor Symposium, (2008).

8）五島彰二, 松永忠雄, 松岡雄一郎, 黒田輝, 江刺正喜, 芳賀洋 一：カテーテル実装に適した血管内 MRI プローブの開発, 電気 学会論文誌 E， 128, 10 (2008) 389. 